\title{
THE ABILITY PROBLEM POSING STUDENTS POST-SOLUTION MATHEMATICAL PROBLEMS BASED ON DIFFERENCES IN LEARNING STYLE
}

\author{
Sembodro Khuzaimatul Ulum \\ Mathematics Education,Faculty of Mathematics and Science,Universitas Negeri Surabaya \\ sembodroulum16030174029@mhs.unesa.ac.id \\ Tatag Yuli Eko Siswono \\ Mathematics Education,Faculty of Mathematics and Science, Universitas Negeri Surabaya \\ tatagsiswono@unesa.ac.id
}

\begin{abstract}
The problem posing ability is making new questions and answers from previous information. Post-solution is modifing a condition of problem solved to submit a new problem. Learning styles in this research is in the form of visual, auditory, and kinesthetic. This descriptive research examines the ability of students to post problem solutions based on differences in learning style involving 10 visual's students, 12 auditory's students, 9 kinesthetic's students. Analysis of data in this research is the data reduction, data presentation, and drawing conclusions. Test material of the test is cubes. The results of the study show that ability problems of student with visual learning styles in the form of problems that can be solved is shown clear information, changing, varying, restating, and grouping in accordance with information about previous questions, direct and indirect answers are arranged in detail, language structure questions in the form of assignment and conditional propositions are shown clear commands, difficulty of easy and moderate difficulty levels in question answer. The ability to submit students' problems in auditory learning styles in the form of problems that can be solved is shown clear information, changing, varying, and restating in accordance with information about previous questions, direct and indirect answers according to the systematic, assignment and conditional propositions according clear problem commands, easy and moderate difficulty levels on question answer. The ability to propose problems of kinesthetic learning styles of students in the form of questions can be solved by manipulating the conditions of the problem, changing, varying, and restarting by manipulating the previous problem, direct and indirect answers according to clear command, assignment and conditional propositions by manipulating the command of the questions, difficulties are easy and moderate arranged in detail.
\end{abstract}

Keywordsproblem posing ability, post-solution, learning style.

\section{INTRODUCTION}

The ability to propose problems is an important thing that students must have. Rahman (2013) explains that the posing of problems has several activities that students have to do, that is, students can create new problems from resolved problems which then use problem solving steps. Supported by Kontorovich et al (2012) problem solving is a special category in problem solving. Based on Siswono (2018: 60) the posing of a problem is one of the steps in solving a problem. Supported by Silver and Cai (1996: 522) students' problem posing abilities have a positive correlation with problem solving abilities. From some opinions show that the ability to submit a problem is closely related to problem solving. The following problem solving steps according to Polya (1973) are: (1) Understanding the problem, (2) Devising a plan, (3) Carrying out the plan, (4) Looking back.

In problem posing, problem solving abilities are very necessary, supported by Siswono (2018) by proposing problems students will easily remember and understand the material for the prerequisites for formulating new problems, and therefore problem solving abilities needs to be possessed by students before asking problems. In other word problem solving is an initial ability that students must have in raising a problem. Understandingproblem posing based on Silver (1994) is formulating questions that are related to the conditions or that are known and that are asked about problems that have been resolved to find alternative solutions to problems or relevant problems. Supported by Siswono (2018: 50) problem posing that is by asking students to make mathematical problems or problems from information that has been given and students can look for a solution to the questions that have been made. Based on Ellerton (2013) the problem posing is not only making new questions, but students can reformulate the problem given by changing or adding information including objects, conditions, and context for the next problem to be solved. In other words, problem posing is obtains from prior problem information from 
independent practice by modifying objects, conditions, and contexts.

In problem posing there are three mathematical cognitive activities based on Silver (1994), namely: (1) presolution posing, (2) within-solution posing, and (3) post- solution posing. In this study using cognitive activity after the solution (post-solution posing), based on the Silver (1994) post-solution posing ie students can modify the goals or conditions of the questions that have been saved to create new questions. Based on Hijriyah (2019) post solution posing can make students more active in learning, develop creative thinking skills, and develop student information and can stimulate students real problems with the information obtained. Post-solution posing was chosen because students had obtained good cube material about surface area and volume, so students had recognized and solved the cube problem beforehand. Cube material can be easily accepted by each learning style, supported by the results of Iraini and Leni's research (2013), that is, each learning style mastering the cube material is shown with a visual learning style capable of mastering $43.48 \%$, auditory learning style capable of mastering $39.13 \%$, and kinesthetic learning style can master $17.39 \%$.

In analyzing of mathematical problem posing, there are several criteria that were adapted based on Siswono (2018: 137), namely: (1) Whether or not a problem can be solved, a problem can be solved if the problem is a problem that contains a mathematical problem and contains information or conditions sufficiently indicated by the formulation of the questions which is clearly stated and the conditions for resolving it can be obtained from the situation or problem that was previously resolved. (2) The relationship of questions with the material posing can be connected with semantic structures (mathematical structures) grouped into five categories as follows: (a) Change is indicated by the questions posing by students using information that is different from the information that was given previously or question that has been solved. (b) Grouping with questions made by students is a combination of any information or questions that have been resolved beforehand. (c) Compare is shown with the questions posing by students having a comparison element with the information that has been given or the previous problem that has been solved. (d) Restate is indicated by the question the student has that has an existing element from the previous information and the settlement can be found directly in the information. (e) Varying is indicated by the problem that the student poses has some data on the situation or information provided and has new data that is different from the initial data provided or the previous problem that has been resolved. (3) The answer to the problem solved is shown by the relationship of mathematical structure (semantics) to the level of complexity which is done by looking at the number of relationships of mathematical structures used to make problems. The answers obtained from the posing of questions that have been made by students, there are answers that can be seen directly from information or situations from questions that have been made, and answers that cannot be completed directly from the information/situation to the problem and need to add information to solve the problem. (4) The structure of the sentence sentences is categorized as follows: (a) the assignment proposition that is the statement directly leads to the task to be done. (b) Relational propositions, namely statements with the nature of comparing. (c) conditional propositions, i.e. statements that contain terms or conditions in the form of implications. (5) There are criteria for problem difficulty as follows. (a) the problem is easily demonstrated by solving it directly without any information processing, but using the application of an existing theory. (b) the question is being indicated by solving not directly using data, it is necessary to process in the form of adding information so that it can be solved by one procedure (c) high problems are indicated by solving not only using existing information but need data processing either by adding other conditions for completion can be with several procedures.

Based on De Porter and Henarcki (2004: 111) in posing problems students have their own way of receiving and processing information obtained in accordance with the way of learning. Based on Dunn and Griggs (2000: 87) there are several components that affect the way of learning, namely (1) Environment, i.e. sound, lights, temperature, and model, (2) Emotional includes encouragement or motivation, conformity with responsibilities, persistence, and structure, (3) Sociology includes learning alone, in pairs or in groups, (4) Psychological includes perception, suggestion, time, and mobility, (5) Overall cognitive character or analysis. Based on Widayanti (2013) learning style is a way of receiving, processing, remembering, and implementing information obtained easily. Learning style has an important role, supported by Soleha et al (2019) learning style has a close relationship with mathematical ability, which leads students to think structurally in processing information. This research is limited learning styles with sensory modalities that use certain zones. De Porter and Henarcki (2004: 112) divide sensory modalities into three, namely visual learning styles, auditory learning styles, and kinesthetic learning styles.

Based on De Porter and Henarcki (2004: 112) Visual learning style is a way of learning that is more dominant using vision. With the characteristics of a visual learning style based on De Porter and Henarcki (2004: 116) as follows: (1) neat and organized in learning, (2) speaking quickly, (3) good planners and regulators, (4) thorough, (5) 
prioritizing appearance, (6) good spelling, (7) easy to remember information, (8) uninterrupted commotion, (9) remembering visual associations that are done alone, (10) fast and persistent readers, (11) views and overall goals, (12) likes to doodle while on the phone, (13) likes to demonstrate rather than make a speech, (14) prefers art to music, (15) sometimes loses concentration. To maximize learning in students' visual learning styles based on Wiedarti (2018), namely: (1) making maps, lines, and drawings for learning, (2) making an outline or core discussion, (3) taking notes, (4) using a color ballpoint to underline, (5) use markers in learning.

Based on De Porter and Henarcki (2004: 112) Auditory learning style is the dominant way of learning utilizing auditory abilities. With the characteristics of auditory learning styles based on De Porter and Henarcki (2004: 118) as follows: (1) likes to talk alone, (2) is easily disturbed by noise, (3) moves the lips and says it while reading, (4) reads aloud, (5) can repeat and imitate the right tone, (6) difficulty writing, (7) prefer music to art (8) Learn by listening and remembering, (9) Like to talk, (10) like to read. To maximize student learning auditory learning styles based on Wiedarti (2018: 17) as follows: (1) forming relationships between words, (2) listening to records, (3) learning by using video, (4) listening from audio books, (5) Reading aloud 6) repeating learning material loudly, (7) love learning together.

Based on De Porter and Henarcki (2004: 112) Kinesthetic learning styles are the dominant way of learning utilizing physical abilities. With kinesthetic learning style characteristics based on De Porter and Henarcki (2004: 118) as follows: (1) Speak slowly, (2) Respond to physical attention, (3) Touch people to get attention, (4) stand close to the listener , (5) lots of movement, (6) manipulating and practice, (7) Memorization by walking, (8) Using fingers when reading, (9) using body cues, (10) hard to remember geography (11) Loving books with action plots (12) the writing is not neat, (13) Like the game. To maximize student learning kinesthetic learning styles based on Wiedarti (2018: 18) as follows: (1) Increase the break time because the participants, (2) practice, (3) Make a visual aid, (4) Follow extracurricular activities, (5) read experience books directly, (6) in groups.

Based on previous research from Halimah (2010) and Sitti (2014) shows that each learning style has a different problem-solving abilities according to the way of thinking and processing information. Therefore, the writing of this article aims to describe the ability to submit students' postsolution problems based on differences in learning styles.

\section{METHODS}

This type of research is a descriptive study. Based on Siswono (2019: 147) descriptive research aims to explain the variables or conditions that are appropriate for a particular situation. This study will describe the ability to submit problem post-solution students based on differences in learning styles. Learning styles in this study are focused on visual learning styles, auditory learning styles, and kinesthetic learning styles. Sources of research data were 31 students from class VIII-A and VIII-C of one of the junior high school in surabaya city. The research subjects were selected by purposive sampling technique with the following considerations being chosen from a particular learning style on the data source and the questions proposed could fulfill the component of the ability to submit a problem with the information presented in full.

In collecting data, there are two research instruments, namely the main instrument and supporting instruments. The main instrument of this study are researchers and supporting instruments using two data collection techniques namely questionnaire and test. The questionnaire used to be a learning style questionnaire adapted from De Porter and Henarcki (2004) with an assessment from Zahar (2009) and the test used was a postsolution type problem posing test.

The research was carried out by giving a learning style questionnaire to classify students based on learning styles, then giving a problem posing test with material to build a flat side space, especially the cube to determine the ability of students to submit problems with the type of postsolution. The following is a problem posing test

\section{kuBus}

Pabrk mengrim sebuah kardux permainaen rubnk kepada sebuah teko mainan Setelah dibongkar terdapat 125 buah rubrik dalamkardus besar yang berbernik kubas tersebua, Jika ukuran nubrik $\$ \mathrm{~cm} \times \$ \mathrm{~cm} \times \$ \mathrm{~cm}$, tentukan.

a. lass permukaan kardus

b. volume kardus

Buatlah đuasoal berbeda berdasiakan informasi y ang telah kamu relesaikan kemudian benkanpenyelesaian dan seal yang telah kamn buat

\section{Figure 1. Problem posing test}

Analysis of the research data was carried out in the stages of data reduction, data presentation, and drawing conclusions. Data from the learning style questionnaire was analyzed by assessment from Zahar (2009) by giving scores to each answer in numbers 1 to 10 (visual) 11 to 20 (auditory) and 21 to 30 (kinesthetic), then adding up the total score obtained, the total level of scores between the questions. Analysis of mathematical problem posing tests, there are several criteria which were adapted based on Siswono (2018: 137), namely problems that can be solved, the relationship of questions with material or previous problems, answers to questions solved, the structure of the sentence language, and the level of difficulty of the questions.

\section{RESULTS AND DISCUSSION}


Based on the results of the learning style questionnaire and the problem posing test on each learning style found 10 students with visual learning styles, 12 students with auditory learning styles, and 9 students with kinesthetic learning styles.

\section{The Ability Problem Posing Subject With A Visual Learning Style}

Next is the ability to problem posingstudents' with a visual learning style.

Table 1. The Ability Problem Posing With A Visual Learning Style

\begin{tabular}{|c|c|c|}
\hline \multicolumn{2}{|c|}{ Components Of Problem Posing } & $\begin{array}{c}\text { The } \\
\text { Number Of } \\
\text { Questions } \\
\text { Raised }\end{array}$ \\
\hline \multicolumn{2}{|c|}{ Questions Can Be Solved } & 20 \\
\hline \multirow{5}{*}{$\begin{array}{c}\text { Related } \\
\text { Questions } \\
\text { With } \\
\text { Material } \\
\text { Or } \\
\text { Previous } \\
\text { Problems }\end{array}$} & Change & 10 \\
\hline & Grouping & 4 \\
\hline & Compare & 0 \\
\hline & Restate & 4 \\
\hline & Varying & 2 \\
\hline \multirow{2}{*}{$\begin{array}{c}\text { Answers } \\
\text { To } \\
\text { Questions }\end{array}$} & Direct Answer & 19 \\
\hline & Indirect Answer & 1 \\
\hline \multirow{3}{*}{$\begin{array}{l}\text { Structure } \\
\text { Of The } \\
\text { Sentence } \\
\text { Language }\end{array}$} & Assignment Proposition & 16 \\
\hline & Relational Proposition & 0 \\
\hline & Conditional Proposition & 4 \\
\hline \multirow{3}{*}{$\begin{array}{l}\text { Difficulty } \\
\text { Level } \\
\text { Problem }\end{array}$} & Easy & 15 \\
\hline & Medium & 5 \\
\hline & High & 0 \\
\hline
\end{tabular}

Here are some examples of the results of problem posing from the subject with a visual learning style.

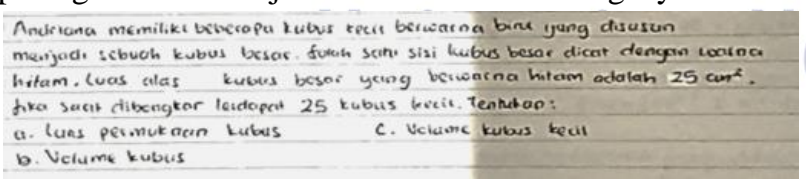

Figure 2. Problem Posing by Visual Subjects

The proposed cube has sufficient information or conditions, indicated by a clear question formulation and problem solving obtained from the existing situation so that categorized questions can be solved.

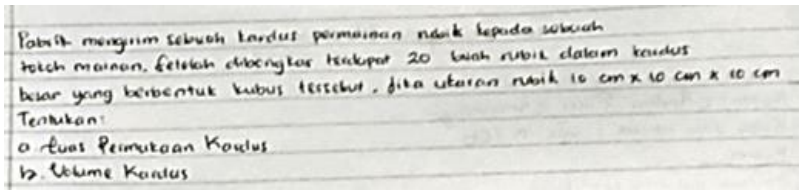

Figure 3. Problem Posing by Visual Subjects
The cube question that is posing has to do with the material or the previous problem, the cube problem isstated by changing because the questions posing using different information from the previous problem but have the same context.

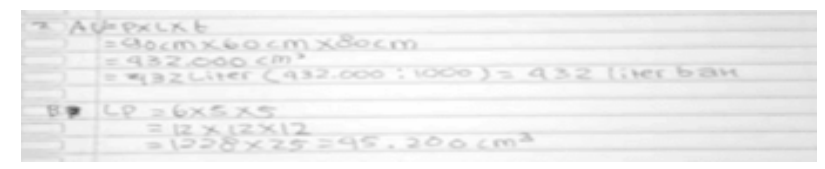

Figure 4. Problem Posing by Visual Subjects

The cube questions posing by the subject relate to the previous material or problem, which is grouped by combining some information from the previous questions that have been solved, the questions proposed have the same type as the command questions about student learning resources or class VIII student textbooks indicated by the answers to the questions arranged according to the surface area of the cube and the volume of the cube.

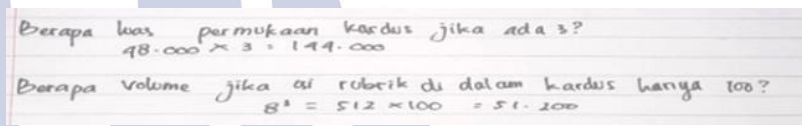

Figure 5. Problem Posing by Visual Subjects

The cube question posing by the subject has to do with the material or the previous problem, which is restating, the information on the question raised obtains from the previous question information by replacing the question command.

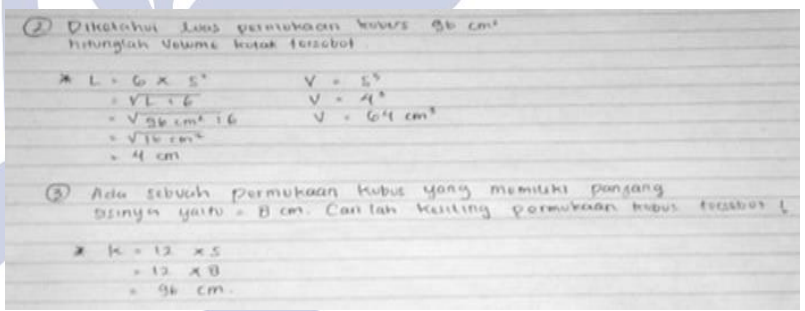

Figure 6. Problem Posing by Visual Subjects

The proposed cube problem has to do with the previous material or problem, which is to vary, which is indicated by new information that is different from the previous problem, question $2 \mathrm{a}$ determines the volume of the cube and $2 \mathrm{~b}$ determines the surface area of the cube.

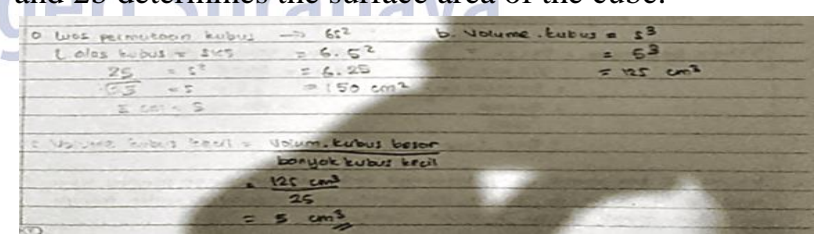

Figure 7. Problem Posing by Visual Subjects

The answer to the cube problem posing by the subject is a direct answer because the answer is obtained from the information contained in the problem without adding new information.

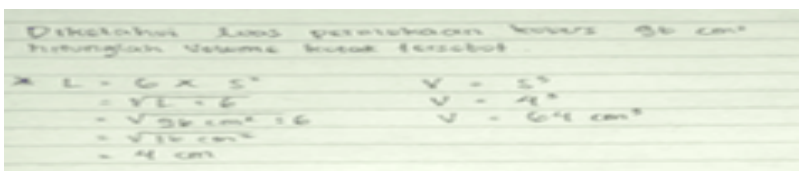


Figure 8. Problem Posing by Visual Subjects

The answer to the cube problem solved by the subject is an indirect answer, an answer Indirectly indicated by an indirect answer found from the information that has been given, to complete the desired answer requires the addition of information. In the matter raised, it is necessary to add information related to the side of the cube which can further determine the volume of the cube.

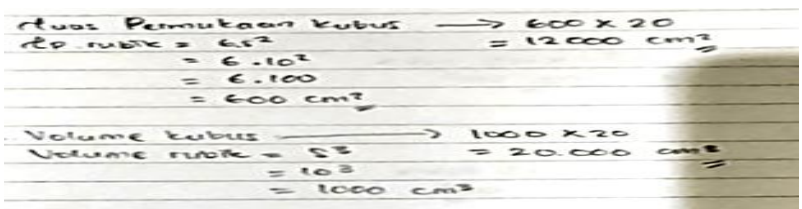

Figure 9. Problem Posing by Visual Subjects

The language structure and sentence sentences used in cube problems posing by the subject constitute an assignment proposition that is stated with the command matter which directly leads to the task without any specific conditions.

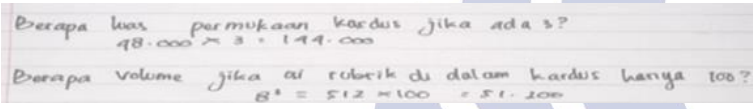

Figure 10. Problem Posing by Visual Subjects

The language structure and sentences of the cube questions posing are conditional propositions, indicated by the order of the problem with certain conditions.

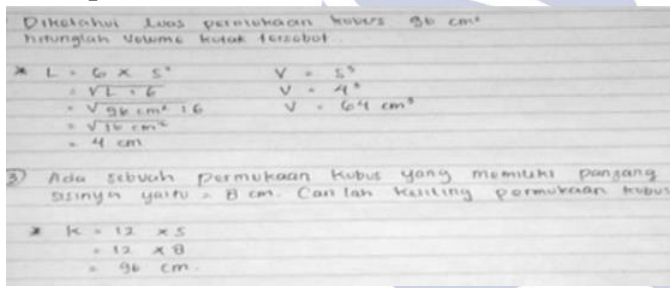

Figure 11. Problem Posing by Visual Subjects

The difficulty level of the proposed cube problem is an easy problem, which is shown by solving the problem obtained directly from the information available without the addition of certain conditions.

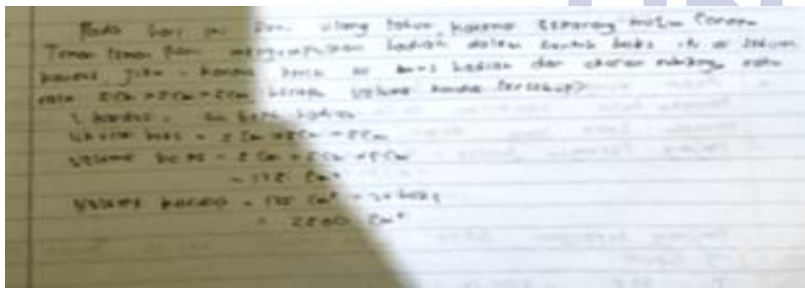

Figure 12.Problem Posing by Visual Subjects

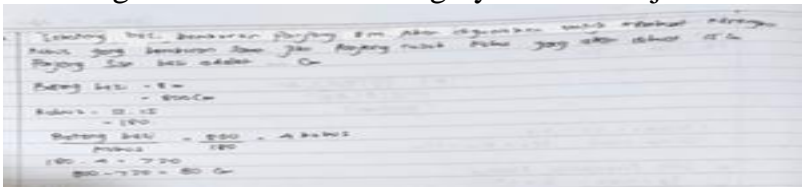

Figure 13.Problem Advanced Posing by Visual Subjects The level of difficulty of the cube problems proposed by subject V04 is a problem with a moderate level of difficulty indicated by the addition of certain conditions to find the desired answer to the problem.
The Ability to Problem Posing Subject Problems With A Auditory Learning Style

Following are the results of students' problem posing tests with auditory learning styles.

Table 2. The Ability Problem Posing With Auditory Learning Style

\begin{tabular}{|c|c|c|}
\hline \multicolumn{2}{|c|}{ Components Of Problem Posing } & $\begin{array}{c}\text { The } \\
\text { Number Of } \\
\text { Questions } \\
\text { Raised }\end{array}$ \\
\hline \multicolumn{2}{|c|}{ Questions Can Be Solved } & 24 \\
\hline \multirow{5}{*}{$\begin{array}{l}\text { Related } \\
\text { Questions } \\
\text { With } \\
\text { Material } \\
\text { Or } \\
\text { Previous } \\
\text { Problems }\end{array}$} & Change & 10 \\
\hline & Grouping & 0 \\
\hline & Compare & 0 \\
\hline & Restate & 6 \\
\hline & Varying & 8 \\
\hline \multirow{2}{*}{$\begin{array}{c}\text { Answers } \\
\text { To } \\
\text { Questions }\end{array}$} & Direct Answer & 22 \\
\hline & Indirect Answer & 4 \\
\hline \multirow{3}{*}{$\begin{array}{l}\text { Structure } \\
\text { Of The } \\
\text { Sentence } \\
\text { Language }\end{array}$} & Assignment Proposition & 16 \\
\hline & Relational Proposition & 0 \\
\hline & Conditional Proposition & 8 \\
\hline \multirow{3}{*}{$\begin{array}{c}\text { Difficulty } \\
\text { Level } \\
\text { Problem }\end{array}$} & Easy & 20 \\
\hline & Medium & 4 \\
\hline & High & 0 \\
\hline
\end{tabular}

The following are a few examples of the results of submitting problems from subjects with auditory learning styles.

\section{Alebuik' kabus herisi seboon toples motconon berbentak kabs dengan ponjung sisi $5 \mathrm{~cm}$. didolom kurdas tersebut berisi 27. toples makoken. Tentuken \\ a) $t p$ kordes \\ or $V$ kordes}

Figure 14. Problem Posing by Auditory Subjects

The proposed cube problem is a question that has clear and detailed information and has the same situation as the previous problem, so that the problem is categorized can be solved.

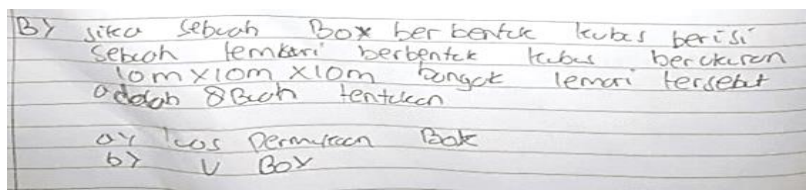

Figure 15.Problem Posing by Auditory Subjects The cube question posing by the subject has to do with the material or the previous problem that is changing, indicated by information that is different from the previous problem. 


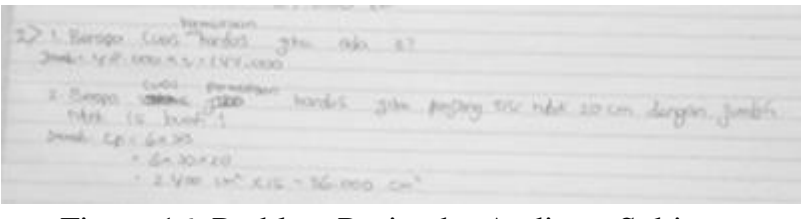

Figure 16. Problem Posing by Auditory Subjects The cube question posing by the subject has to do with the material or the previous problem, which is restating, the information on the question used is the same as the previous problem, but there is only the addition of information to the question command in the form of special conditions on the question command.

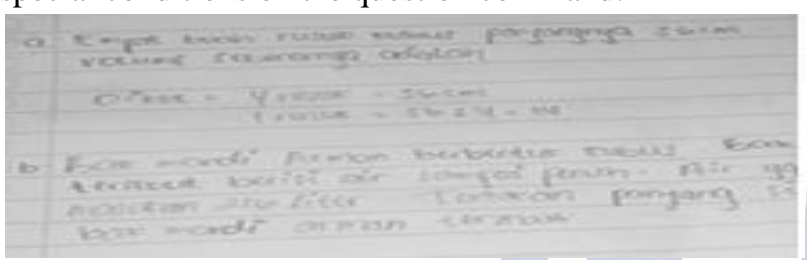

Figure 17.Problem Posing by Auditory Subjects

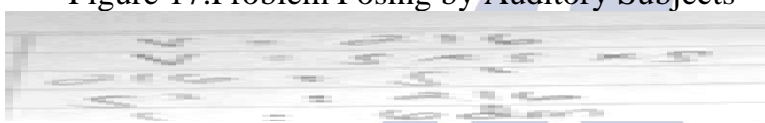

Figure 18.Problem Posing Advanced by Auditory Subjects

The cube question posing by the subject has to do with the material or previous problem, which is to vary. Varying is indicated by the information posing on the problem having different data from the previous problem.

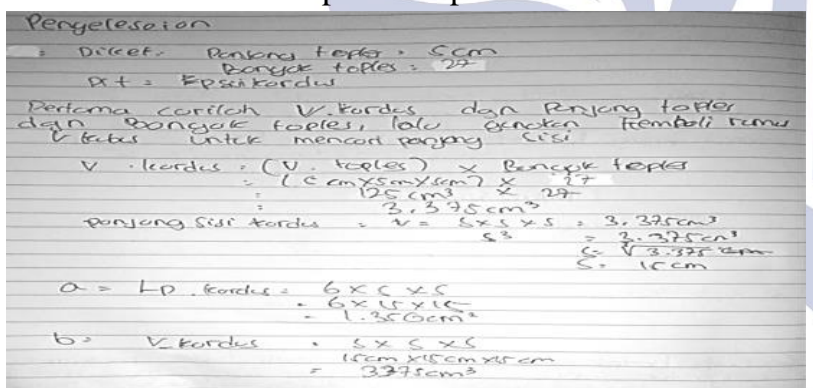

Figure 19. Problem Posing by Auditory Subjects The answer to the cube question posing by the subject is an indirect answer because in determining the settlement, it is necessary to determine other conditions or conditions in the problem.

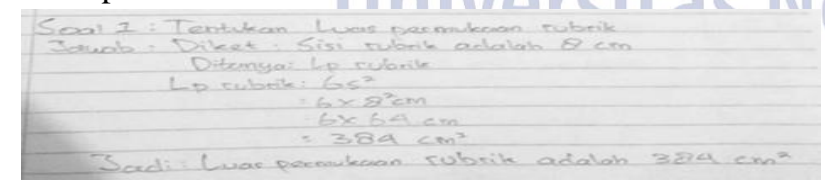

Figure 20. Problem Posing by Auditory Subjects

The answer to the cube problem posing by the subject is a direct answer. Direct answers are shown with brief information as well as routine settlement used in the questions posing.

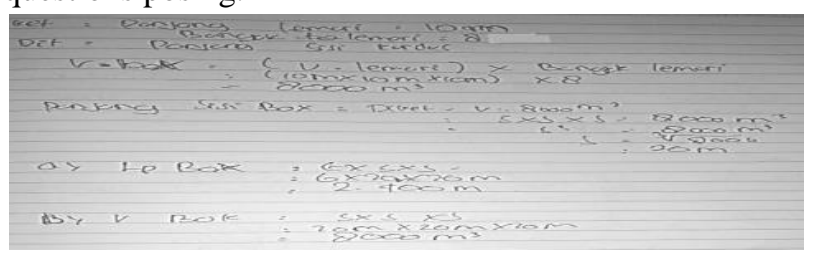

Figure 21. Problem Posing by Auditory Subjects The language structure and sentence about the cube used are assignment propositions shown by direct written, clear question commands that lead to problem solving.

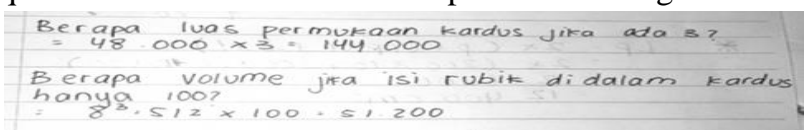

Figure 22. Problem Posing by Auditory Subjects

The language structure and sentence about the cube proposed by the subject are conditional propositions. Conditional propositions are indicated by the special conditions in the question order posing by the subject and the same information as the previous problem.

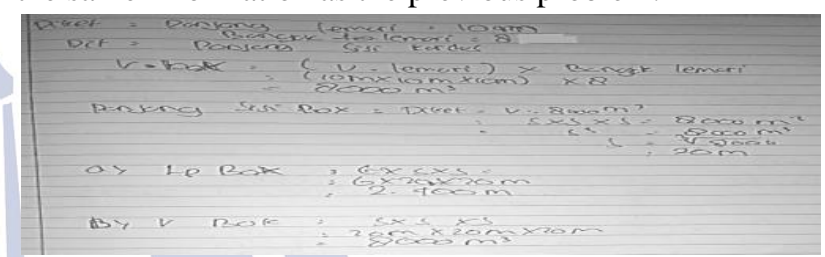

Figure 23. Problem Posing by Auditory Subjects

The proposed cube problem is a problem with a moderate level of difficulty because to solve the problem, it is required to add or determine information as a condition to get a solution or an appropriate answer.

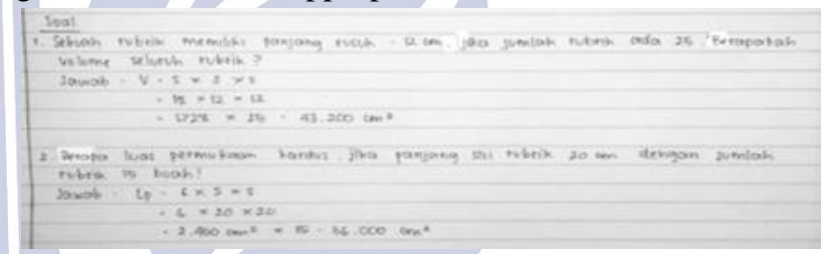

Figure 24. Problem Posing by Auditory Subjects

The level of difficulty of the cube questions posing by the subject is easy. Problems that have difficulty levels are easily shown by the information the given problem can be used directly without adding certain terms or conditions to solve the problem.

The Ability Problem Posing Subjects With A Kinesthetic Learning Style

The following are the results of a kinesthetic learning style, subject matter test.

Table 3. The Ability Problem Posing With a kinesthetic

\begin{tabular}{|c|c|c|}
\hline \multicolumn{2}{|c|}{ Components of problem posing } & $\begin{array}{c}\text { The } \\
\text { number of } \\
\text { questions } \\
\text { raised } \\
\end{array}$ \\
\hline \multicolumn{2}{|c|}{ Questions can be solved } & 18 \\
\hline \multirow{4}{*}{$\begin{array}{l}\text { Related } \\
\text { questions } \\
\text { with } \\
\text { material or } \\
\text { previous } \\
\text { problems }\end{array}$} & Change & 6 \\
\hline & Grouping & 0 \\
\hline & Compare & 0 \\
\hline & Restate & 4 \\
\hline
\end{tabular}




\begin{tabular}{|c|c|c|}
\hline \multicolumn{2}{|c|}{ Components of problem posing } & $\begin{array}{c}\text { The } \\
\text { number of } \\
\text { questions } \\
\text { raised }\end{array}$ \\
\hline & Varying & 8 \\
\hline \multirow{2}{*}{$\begin{array}{c}\text { Answers to } \\
\text { questions }\end{array}$} & direct answer & 18 \\
\cline { 2 - 3 } & Indirect answer & 0 \\
\hline \multirow{3}{*}{$\begin{array}{c}\text { Structure } \\
\text { of the } \\
\text { sentence } \\
\text { language }\end{array}$} & Assignment Proposition & 18 \\
\cline { 2 - 3 } & Relational Proposition & 0 \\
\cline { 2 - 3 } & Conditional proposition & 0 \\
\hline \multirow{2}{*}{$\begin{array}{c}\text { Difficulty } \\
\text { level } \\
\text { problem }\end{array}$} & Easy & 18 \\
\cline { 2 - 3 } & Medium & 0 \\
\cline { 2 - 3 } & High & 0 \\
\hline
\end{tabular}

Here are a few examples of the results of incorrect problem posing of subjects with kinesthetic learning styles

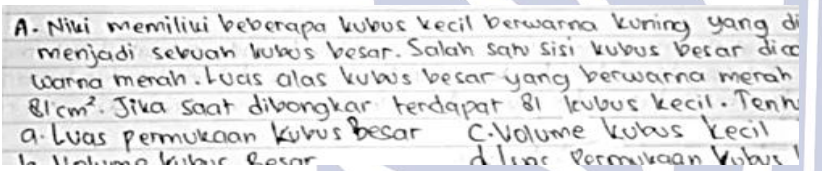

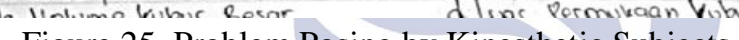

Figure 25. Problem Posing by Kinesthetic Subjects Problem cubes posing by the subject. have detailed information with the same situation as the previous problem so that the problem can be categorized as solved.

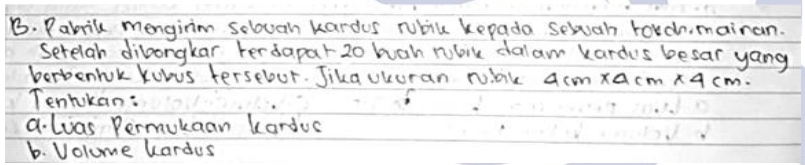

Figure 26. Problem Posing by Kinesthetic Subjects The proposed cube has a connection with the material or the previous problem is changing, expressed by the difference in information from the previous problem by modifying the problem.

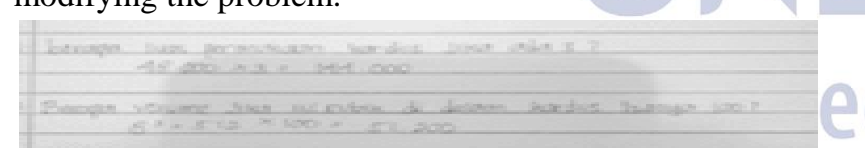

Figure 27. Problem Posing by Kinesthetic Subjects The questions raised by the subject have to do with previous material or questions, which are restating. With the same questionable information from the previous question with the change in command about the problem.

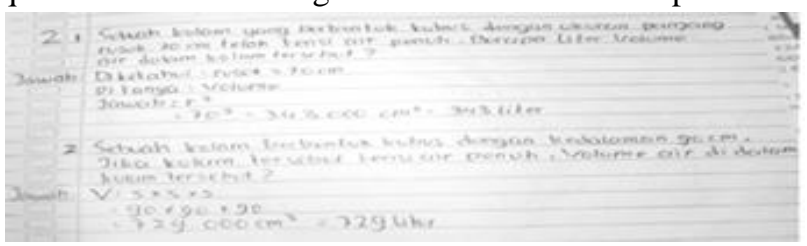

Figure 28. Problem Posing by Kinesthetic Subjects The cube question posing by the subject is related to the previous problem, which is to vary. Variety is indicated by new information on the questions raised, indicated by determining the volume of the cube on the questions posing by subjects that are different from the previous questions.

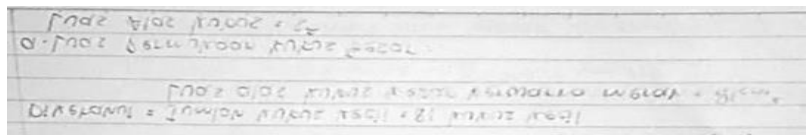

Figure 29. Problem Posing by Kinesthetic Subjects

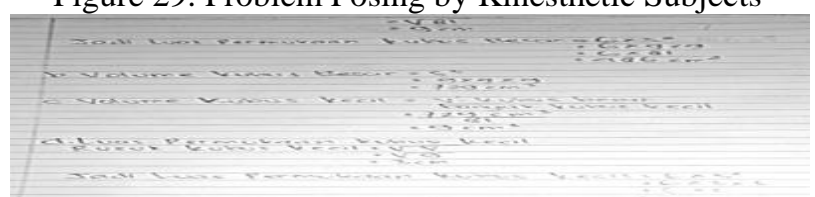

Figure 30. Problem Posing Advanced by Kinesthetic Subjects

The cube question answers posing by the subject are direct answers, indicated by the solution of the questions obtained from existing information without the addition of certain conditions.

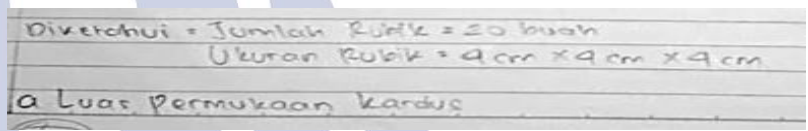

Figure 31. Problem Posing by Kinesthetic Subjects

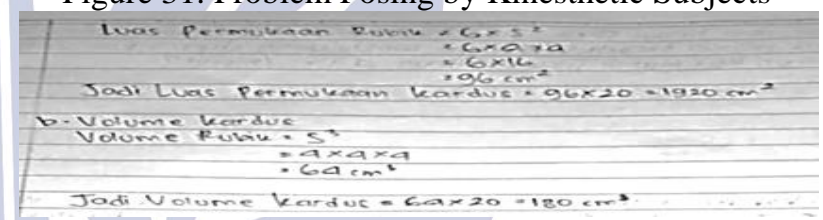

Figure 32. Problem Posing Advanced by Kinesthetic Subjects

The structure of language and sentence about a cube is an assignment proposition, indicated by a mature command that leads to a task without any specific conditions.

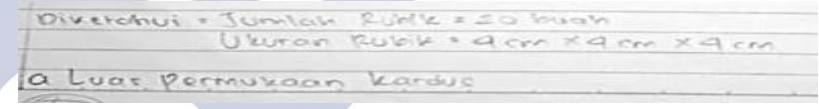

Figure 33. Problem Posing by Kinesthetic Subjects

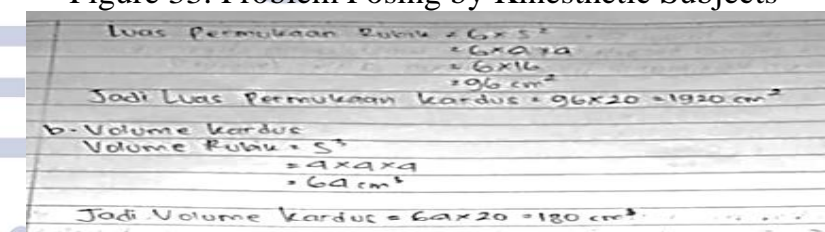

Figure 34. Problem Posing Advanced by Kinesthetic Subjects

The difficulty level of the questions posing by the subject is an easy category problem, indicated by the solution of the questions obtained from the information available on the problem without the addition of certain conditions.

\section{Discussion}

\section{Problem posing ability with visual learning style}

Subjects with visual learning styles can fulfill several components of problem posing, namely problems can be solved by neatly written questions and orderly according to the characteristics of visual learning styles are shown clear and detailed information and written carefully, the problem situation proposed is a modification of the 
previous problem in accordance with the characteristics of a visual learning style that is easy to remember information and visual associations that are done alone so that problems can be categorized can be solved. The questions proposed have the category of changing, varying, restating, and grouping indicated by the characteristics of a visual learning style that is easy to remember information visually so that it can create problems by combining a number of questions from the completed problems. Direct answers and indirect answers are used on questions raised by visual learning style subjects with written answers in detail accordingly with the characteristics of a visual learning style of good planners and regulators. The language structure of the sentence sentences used in cube problems is a matter of the assignment proposition and the conditional proposition is shown by the statement of the order of the questions arranged in detail which shows the subject of visual learning style is a good planner. The proposed cube has a difficulty level that is easy and is being indicated by the questions and the answers proposed have a solution that is in accordance with what is desired by the problem in accordance with the characteristics of a visual learning style that is a good planner and regulator. Supported by research results from Saraswati and Masruroh (2014) showing that subjects with a visual learning style read post-solution questions more than once read silently, posing of questions is shown by changing the context of information and solving different from the previous questions, solving, written problems neatly and systematically, the subject can determine an appropriate solution based on the completion of the previous problem, the subject checks the settlement again by checking the settlement of the previous problem. Supported by research from Halimah (2010) explaining that subjects with a visual learning style make questions that are different from previous problems, accompanied by varying and correct solutions, the subject is able to distinguish between the questions raised from the previous questions. Supported by the results of research from Sitti (2014) explaining that the subject of visual learning styles can optimize learning styles in understanding information well, the questions posing by the subject have varied statements using elements of assignment, relationships, and presuppositions.

\section{Problem posing ability with auditory learning style}

The auditory learning style, subject can fulfill several components of problem posing ability, that is, the problem can be solved, which is shown with concise, concise, and clear information according to the auditory learning style characteristics that are more likely to be easier to tell them to write so that the subject of auditory learning style write questions briefly. The questions proposed have to do with the material or previous problems with the criteria of restating, changing, and varying indicated by the questions proposed having the same conditions as the previous questions that are in accordance with the characteristics of the auditory learning style, namely being able to repeat and imitate rhythm appropriately and be able remember information that is heard so that the subject is able to submit questions with the same conditions. The answers to the questions raised are indirect and direct answers are indicated by the characteristics of the auditory learning style that is able to repeat and mimic the rhythm correctly, so that the answers are arranged well planned in accordance with the questions that have been resolved. Language and question sentences are assignment propositions shown by convoluted questions that lead directly to completion and conditional propositions with questions directed to specific conditions briefly, in accordance with the characteristics of auditory learning styles ie prefer to speak rather than write so that language which is used in direct and clear matter commands. The level of difficulty of the questions posing has a moderate and easy level of difficulty indicated by information about questions and answers that are short, concise, and clear. Supported by research from Halimah (2010) explaining the questions proposed by the subject of auditory learning style has a variety of questions with complete information in different contexts, the solution of the questions proposed is different from the resolution of the previous questions, the sentence structure used in the questions proposed is not double meaning. Supported by Sitti's research results (2014) showing subjects with auditory learning styles are able to optimize learning styles by understanding information well, the questions posed vary indicated by new data combined with previous data or information.

\section{Problem posing ability with kinesthetic learning style}

Subjects with kinesthetic learning styles that can meet the problem solving component, i.e. problems that can be solved, are shown with solid and clear information about problems. The questions proposed have to do with previous material or questions, namely changing, varying, restating, indicated by the characteristics of kinesthetic learning styles, which are able to manipulate and practice in remembering information so that they are able to submit questions with the same problem conditions as the general questions. The answer to the cube problem is the direct answer shown by manipulating the answer to the previous problem so that the answer has the same conditions. The structure of the sentence sentences used in cube problems is an assignment proposition in accordance with the characteristics of kinesthetic learning styles that are able to manipulate and practice in remembering information so that the questions proposed are manipulations of the language of the previous questions. The difficulty level of 
the questions proposed is an easy question arranged in detail and clearly in accordance with the characteristics of the kinesthetic learning style that is like a plot that reflects the action indicated by information and commands on the problem. Supported by Halimah's research (2010) explaining the questions proposed by subjects with kinesthetic learning styles is a variety of questions, the sentence structure is easy to understand and does not have multiple meanings, the proposed problem solving plan is different from the previous questions. Supported by the results of research from Sitti (2014) explains that subjects with kinesthetic learning styles can understand the information well that is indicated by the posing of questions that connect new data with previous data.

The explanation above shows that the subject with each learning style can represent all components of the posing of the problem.

\section{CLOSURE}

\section{Conclusion}

Based on the discussion above, it can be seen that the learning styles possessed by students have a role in raising the problem. There are differences in the ability of students to submit problems with visual learning styles, auditory learning styles, and kinesthetic learning styles. Next is the ability to submit students' problems with differences in learning styles.

The ability to submit students' problems post-solution with a visual learning style can fulfill several components, namely the problem can be solved, the problem posed has a connection with the material or the previous problem in the form of changing, varying, restating, and classifying, the answer to the question raised in the form of direct answers and answers indirectly, the language structure and sentence of questions raised about questions are assignment propositions and conditional propositions, the level of difficulty of questions raised is easy and moderate difficulties.

The ability to submit post-solution students' problems with auditory learning styles is able to fulfill several components, namely the problem can be solved, the problem posed has a connection with the previous problem in the form of restating, changing, varying, the answer to the question raised is a direct answer and an indirect answer, structure the language and sentence sentences used are assignment propositions and conditional propositions, the difficulty level of the questions raised is easy and moderate difficulty.

The ability to submit students' problems post-solution with kinesthetic learning style is able to meet several components, namely the problem can be solved, the problem posed has a connection with the material or the previous problem in the form of varying, restating, and changing, the answer to the question raised is a direct answer, the structure of language and the sentence sentences is an assignment proposition, the difficulty level of the questions raised is easily difficulty.

\section{Suggestion}

1. The test results show that the relation of questions with the previous material, mostly fulfills the type of changing, restating, and varying, so the teacher must provide practice questions with the type of comparing and grouping, so that the ability to raise problems is more varied.

2. It is suggested to other researchers who will follow up on this research to pay attention to the details of students 'behavior when working on a problem posing test and conduct interviews so that the ability to submit students' problems in each learning style can be clearly seen.

\section{REFRENCES}

De porter, Bobbi \& Hernacki, Mikke. 2004. Quantum Learning: Membiasakan belajar Nyaman dan Menyenangkan.Terjemahan oleh Alwiyah Abdurahman. Bandung: Kaifa.

Dunn,Rita \& Griigs, Shirley. 2000.Practical Approaches to Using Learning Style in Higher Education. London: Greenword Publishing Group.

Ellerton, Nerlda.F. 2013. Engaging pre-service middleschool teacher-education students in mathematical problem posing: development of an active learning framework. Educ Stud Math 83:87-101 Springer

Halimah, Nur. 2010. Tingkat Kemampuan Berpikir Kreatif Siswa Bergaya Belajar Visual, Auditori, Kinestetik Dalam Pengajuan Dan Pemecahan Masalah Matematika Dengan Informasi Berupa Gambar Bangun Datar Di Kelas VII SMP Negeri 13 Surabaya. Pps Institut Agama Islam Negeri Sunan Ampel Surabaya.

Hidayat, Wahyu \& Sariningsih, Ratna. 2018. Kemampuan Pemecahan Masalah Matematis dan Adversity Quotient Siswa SMP Melalui Pembelajaran OpenEnded: Jurnal Nasional Pendidikan Matematika Vol.2 Hal.109.

Hijriyah, U . Pratiwi ,E. Susanti, A. Anggaini, W. \& Febriani, P. 2019. The effect of problem posing type post-solution posing learning model on selfregulation skills and science process skill of the tenth-grade student of Islamic senior high school kebumen, tanggamus. Jounal of Physics: Conf. Series 1467(2020) 012042.

Iraini, Dewi \& Leni, Mutia. 2013. Identifikasi Gaya Belajar Dan Pengaruhnya Terhadap Hasil Belajar Pada Materi Kubus Kelas VIII SMPN 2 Kerici. Prosiding semirata FMIPA Universitas Lampung.

Kontorovich, I., Koichu, B., Leikin, R., \& Berman, A.2012. An Exploratory Framework for Handling the Complexity of Mathematical Problem Posing in Small Groups: Journal of Mathemathical Behavior, 31(1):149-161. 
Polya, G.1973. How To Solve It. A New Aspect Of School Mathematical Method. Princeton dan New jersey: Princeton University Press.

Rahman, Abdul. 2013. Pengajuan Masalah Matematika Ditinjau Dari Gaya Kognitif Dan Kategori Informasi: FMIPA Universitas Neger iMakasar.

Saraswati, Esty \& Masruroh, Faridatul. 2014. Proses Berpikir Mahasiswa Dengan Gaya Belajar Visual Dalam Mengajukan Soal Matematika Tipe PostSolution Posing. Al-Khawarizmi Vol.II hal 29-46.

Silver, Edward.A. 1994. On Mathematical Problem Posing: Vol.14 Hal.19 - 28.

Siswono,Tatag.Y.E. 2018. Pembelajaran matematika berbasis pengajuan dan pemecahan masalah. Bandung: Rosdakarya.

Siswono,Tatag.Y.E. 2019. Paradigma Penelitian Pendidikan. Bandung: Rosdakarya.

Sitti, Rahmayani. 2014. Deskripsi Kemampuan Pengajuan Masalah Pada Materi Sistem
Persamaan Linear Dua Variabel Ditinjau Dari Gaya Belajar Siswa Kelas X3 SMA Negeri 1 Mattirosompe. Allen Institute for al corpus id 151807177.

Soleha, Rasiman, \& Purwosetyono. 2019. Analisis kesulitan siswa dalam menyelesaikan masalah matematika ditinjau dari gaya belajar siswa SMK. Imaginer: jurnal Matematika dan Pendidikan Matematika ISSN 2685-3892.

Widayanti, FebiDwi. 2013. Pentingnya mengetahui gaya belajar siswa dalam kegiatan pembelajaran di kelas: ERUDIO Vol.2 ISSN 2302-9021.

Wiedarti, Pangesti.2018.Seri Manual GLS Pentingnya Memahami Gaya Belajar.Jakarta :Kementerian Pendidikan dan Kebudayaan.

Zahar, Iwan. 2009. Belajar Matematikaku: embela jaran Matematika Secara Visual dan Kinestetik. Jakarta :Elek Media komputido.

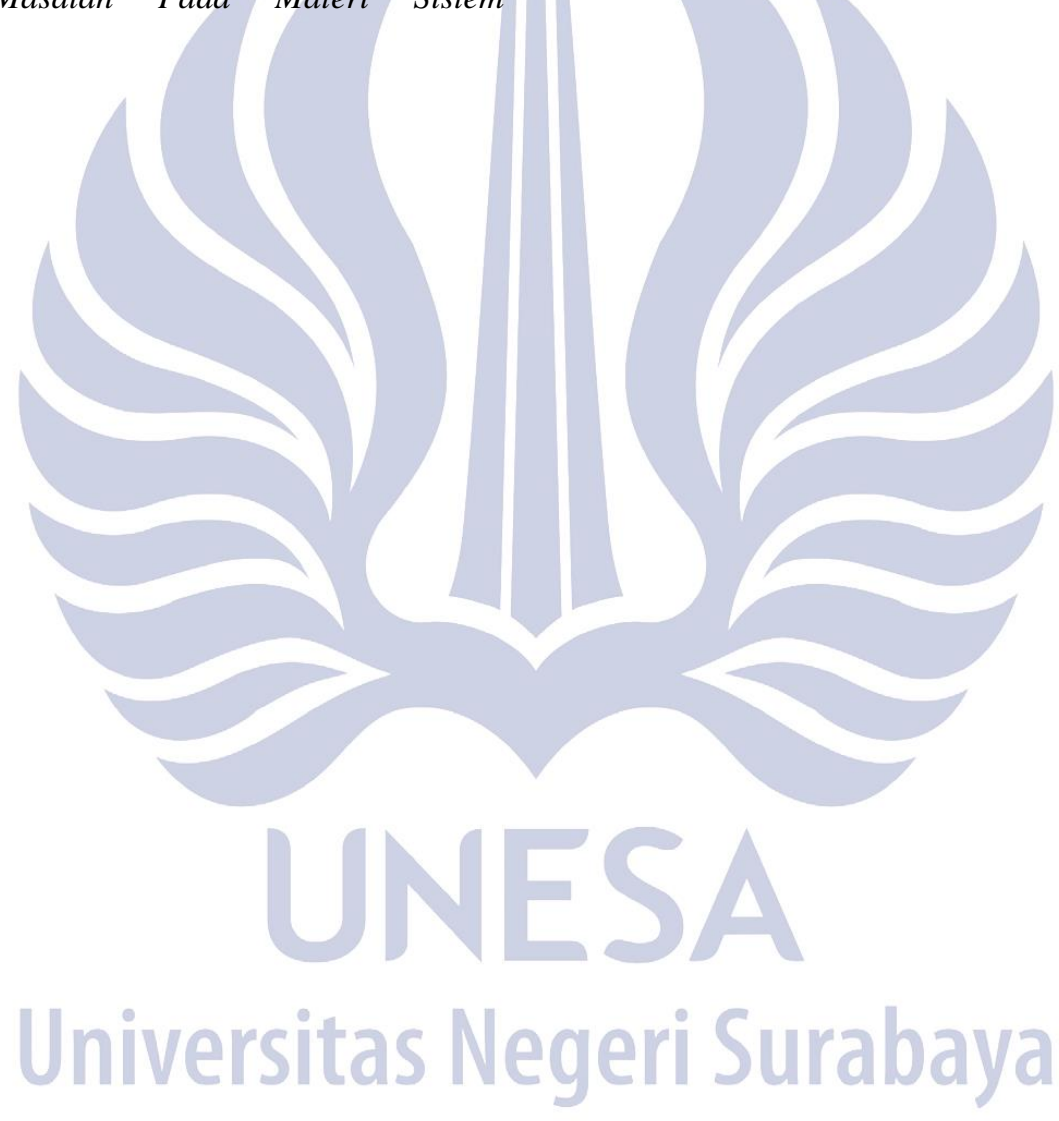

